\title{
Dental anxiety level of children patient during dental treatment using CFSS-DS questionnaire
}

\author{
Mutiara Yuwannisa*, Jakobus Runkat*, Ratna Indriyanti* \\ *Department of Pedodontics Faculty Of Dentistry Universitas Padjadjaran
}

\begin{abstract}
The anxiety during dental treatment is an obstacle for both adult and children patients. The aim of this study was to describe data of the dental anxiety experienced by 6 - 9 year old patients grouped by their age and gender. The type of this study was descriptive observational and the samples were collected using incidental sampling method. The total number of sample were 63 patients who came to Dental Hospital of Faculty of Dentistry Universitas Padjadjaran Bandung during August 2011. This research was using the CFSS-DS questionnaire to measure the patient's anxiety. This research was conducted by interviewing the patients about how they feel during the dental treatment. The result of this study showed that the 7-years-old boy patients seem to have higher anxiety levels than the 6-years-old, or younger ones. Meanwhile, in 6-years-old and younger girl patients showed higher anxiety level than the older $(7,8$, and 9 -year-old) ones. The anxiety level of children patients during dental treatment were different based on their age and gender.
\end{abstract}

Keywords: Dental anxiety level, children aged 6-9 years old, dental treatment, CFSS-DS questionnaire

\section{INTRODUCTION}

Anxiety derived from the latin word "angustus" means stiff and "ango, anci", means choking. Freud stated that anxiety is an ego function to warn an individual about the probability of incoming danger, so one can readily prepare appropriate adaptive reaction. The function of anxiety is as a mechanism that protect ego, because it gives signal to us that there is danger, and therefore, if there is no appropriate action, then the danger will increase until the ego is lost. ${ }^{1,2}$

In 1995, Taylor had mentioned that anxiety is a subjective experience about mental tension that gives a restless general reaction and inability to deal with problems, or, no safe feeling. Normally, this unpleasant feeling causes some physiological symptoms (such as shaking, sweating, increasing heart beat, etc.) and psychological symptoms (such as panic, tense, confused, inability to concentrate, etc.). ${ }^{3,2}$

Anxiety is different from fear. Anxiety emerges as the consequences of thinking an object or something that is not clear and not yet happen, in contrast to fear, occurs as the result of thinking an object or something that is clear and specific. ${ }^{4}$ Anxiety is a challenge for patient, adult or children, in applying dental treatment. Nowadays, there are many adult patients that delaying, even declining or avoiding dental treatment because of their anxiety and fear to receive dental treatment. This condition is 
developed from childhood and becoming a fear, which is difficult to manage. ${ }^{5}$

Corah in 1978 had identified in his experiment that anxiety of patient that is undergone dental treatment is the biggest challenge to establish a routine dental healthcare. Survey in 6000 people stated that $58 \%$ respondent the reason behind their delayed dental treatment is because of their fear to the dentist. To that reason, the problem about anxiety needs to be handle with serious attitude. ${ }^{5}$

Children ages 6-9 years is the period when children entering new environment, or school environment. In this period, children adapt and have activities together with their new friends and teachers. Before, they are contented with their family life, however, when entering the school period, they are facing social life and need to self-adjust and adapt better. This anxiety, that the children feel when doing dental visit to the dentist, is obvious, even when they are about to enter the dental practice room. The dentists' appearance, practical instruments, the smell of medicine and the sound produced by the dental tools tend to scare the children. One of main reason children refuse their teeth to be checked is because of seeing the dental instruments, which is considered for them terrifying. ${ }^{7}$

The behavioral manifestations of anxiety when dealing with dental treatment are rejecting to open their mouth, crying, creaming, kicking, hiding, resisting to be separated from their parents, and refusing to enter the dental practice room. Anxiety causes children unable to cooperative when receiving dental treatment procedure from the dentist, avoiding treatment, canceling the appointment, being late on appointment, making the routine treatment difficult, unable to remember and doing dental instruction from dentist, therefore, decreasing the efficiency and effectivity of dental health service. ${ }^{7}$

The variety of tools for measuring the level of anxiety is Corah Dental Anxiety Scale (DAS), The Venham Picture Test (VPT), and Children's Fear-Dental Survey Subscale (CFSS Schedule-DS). CFFS-DS is a revision from Fear Survey Schedule for Children (FSS-FC) that including specific dental fear as one of the sub-scale. CFSS-DS, which is developed by Cuthbert and Melamed, consists of 15 variables and each variable represent a different aspect from dental situation like invasive dental treatment, such as injection and preparation, as well as general medical aspect. The aim of this study was to describe data of the dental anxiety experienced by $6-9$ year old patients grouped by their age and gender using the CFSS-DS Questionnaire.

\section{METHODS}

This research was an observational descriptive research, which aimed to describe a situation based on the result of direct observation. ${ }^{9}$ The study population was children aged 6-9 year, which was having their first dental visit to the dental clinic and willing to be in the research and sign informed consent during August 2011.

The sample selection was done using incidental sampling technique. Incidental sampling is a sample determination technique based on chance, which was anyone who accidentally / incidentally met the researcher can be used as a sample, if deemed suitable as a source of data. ${ }^{10}$ Sampling was determined based on the criteria and considerations of the researcher.

The inclusion criteria were as follows: Boys and girls, aged 6-9 years old, having their first dental clinic visit, and parents or guardians were willing to fill in informed consent. The number of samples was determined by using the consecutive sampling procedure, which was the sampling method that selected every subject available from the study population and can be used as research data. ${ }^{11}$ The tools and materials used in this study were as follow: Stationery kit, informed consent containing patient name, patient age, gender, parent's name, parent's age, address, and parent's occupation, the Children's Fear Dental Survey Subscale (CFSS-DS) questionnaire consisted of 15 questions, hand mirror, dental explorer, forceps, masks, gloves, alcohol, and cotton.

\section{RESULTS}

The results of research on children's anxiety level on dental treatment will be described by age and gender. The number of samples in this study was 63 patients, which were children aged 6-9 years that had their first dental visit to the clinic at Dental Hospital of Faculty of Dentistry Universitas 
Padjadjaran Bandung during August 2011.

Characteristics of respondents were grouped by gender and age of the child. Figure 1 and Figure 2 illustrated the characteristics of 63 patients, which were children aged 6-9 years that had their first dental visit to the dental clinic at Dental Hospital of Faculty of Dentistry Universitas Padjadjaran Bandung (Figure 1 and 2).

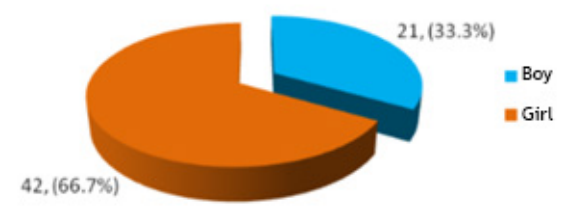

Figure 1. Distribution of respondents based on gender

In Figure 1 can be seen the majority of children that had their first dental visit to the clinic at Dental Hospital of Faculty of Dentistry Universitas Padjadjaran Bandung were girls. Boys were as much as 21 people or $33.3 \%$ of the total of 63 children who became the study sample.

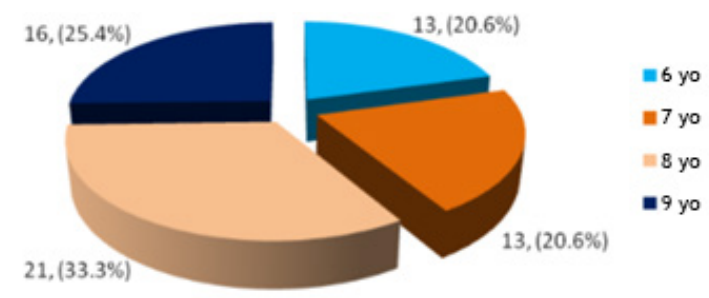

Figure 2. Distribution of respondents based on age

Respondents distribution based of age was showed in Figure 2, can be seen that most children that had their first dental visit to the clinic at Dental Hospital of Faculty of Dentistry Universitas Padjadjaran Bandung were 8 years old with as much as 21 children or equal to $33.3 \%$ of the total sample. The fewest respondents were groups of children aged 6 years and 7 years old, which were 13 people or $20.6 \%$ of the total study sample.

Based on age category, most children aged 7 years old did not feel anxious about dental treatment $(54.9 \%)$, followed by groups of children ages 8 and 9 years (52.5\%), and groups of children aged 6 years (49.7\%). The children that felt slightly anxious were in the 9-year age group $(26.7 \%)$, followed by the 6 -year age group (25.1\%) and the age group of 7 and 8 years $(24.1 \%$ and $2.4 \%$ ). The group of children that had highest number of anxious was the age group of 6 years (25.1\%), followed by the age group of 7 years $(19.0 \%)$ and the age group of 8 and 9 years (@ $18.1 \%$ and $18.3 \%$ ). The group of children what had the highest number of very anxious was in the 8-year age group (3.5\%), followed by the 9-year age group (2.5\%) and the age group of 6 and 7 years (@ $0.0 \%$ and 1.0\%). While the extremely anxious group of children is found in the age group of $7(1.0 \%)$ and 8 years $(1.3 \%)$, while children aged 6 and 9 years none showed extremely serious anxiety (Table 1).

Based on gender can be seen that most boys were not worried about dental treatment (45.1\%), then a slight anxiety of $28.9 \%$, but the anxiety in dental care is also still quite a lot, that is $21.9 \%$. In girls, most were not anxious about dental treatment (56.2\%), slightly anxious $23.2 \%$, anxious in dental treatment of $18.7 \%$, very anxious $1.4 \%$ and extremely anxious $0.5 \%$ (Table 1 ).

The average level of anxiety levels of children on dental treatment (Figure 3) showed that children of male sex generally had higher anxiety than children of female sex. In boys aged 7 years actually had anxiety higher than children who were younger (6 years). The opposite was seen in girls. Younger children (6 years) generally had higher anxiety than older children (7 years, 8 years and 9 years).

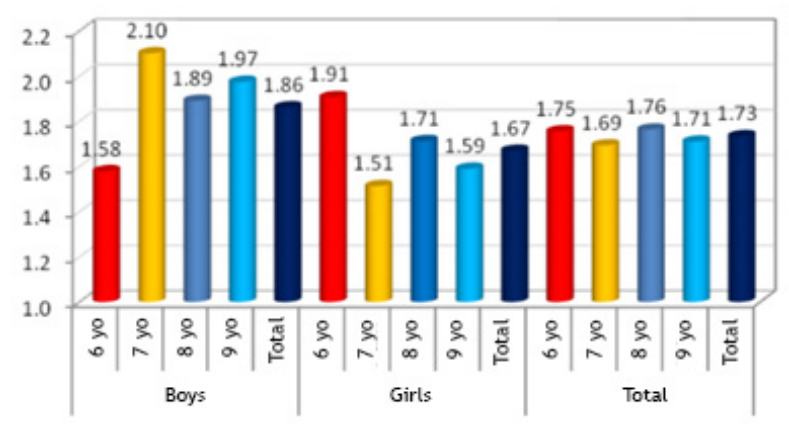

Figure 3. Average level of anxiety on children towards dental treatment based on age and gender

Table 2 presented the source of anxiety, and showed that most boys felt anxious about choking (57.1\%) and anxiety about the syringe (52.4\%). These data suggest that boys were generally anxious to be choked and syringes during dental treatment (Table 2). 
Table 1. Level of children dental anxiety on dental treatment based on age and gender

\begin{tabular}{|c|c|c|c|c|c|c|c|c|c|c|c|c|}
\hline \multirow{2}{*}{ Gender } & \multirow{2}{*}{ Age } & \multicolumn{2}{|c|}{ Not anxious } & \multicolumn{2}{|c|}{$\begin{array}{l}\text { Slightly } \\
\text { anxious }\end{array}$} & \multicolumn{2}{|c|}{ Anxious } & \multicolumn{2}{|c|}{ Very anxious } & \multicolumn{2}{|c|}{$\begin{array}{l}\text { Extremely } \\
\text { anxious }\end{array}$} & \multirow{2}{*}{ Average } \\
\hline & & $f$ & $\%$ & $f$ & $\%$ & $f$ & $\%$ & $f$ & $\%$ & $f$ & $\%$ & \\
\hline \multirow[t]{5}{*}{ Boys } & 6 years old & 51 & 56.7 & 26 & 28.9 & 13 & 14.4 & 0 & 0.00 & 0 & 0.00 & 1.58 \\
\hline & 7 years old & 22 & 36.7 & 16 & 26.7 & 18 & 30.0 & 2 & 3.3 & 2 & 3.3 & 2.10 \\
\hline & 8 years old & 41 & 45.6 & 26 & 28.9 & 16 & 17.8 & 6 & 6.7 & 1 & 1.1 & 1.89 \\
\hline & 9 years old & 28 & 37.3 & 23 & 30.7 & 22 & 29.3 & 2 & 2.7 & 0 & 0.00 & 1.97 \\
\hline & Total & 142 & 45.1 & 91 & 28.9 & 69 & 21.9 & 10 & 3.2 & 3 & 1.0 & 1.86 \\
\hline \multirow[t]{5}{*}{ Girls } & 6 years old & 46 & 43.8 & 23 & 21.9 & 36 & 34.3 & 0 & 0.00 & 0 & 0.00 & 1.90 \\
\hline & 7 years old & 85 & 63.0 & 31 & 23.0 & 19 & 14.1 & 0 & 0.00 & 0 & 0.00 & 1.51 \\
\hline & 8 years old & 125 & 55.6 & 51 & 22.7 & 41 & 18.2 & 5 & 2.2 & 3 & 1.3 & 1.71 \\
\hline & 9 years old & 98 & 59.4 & 41 & 24.8 & 22 & 13.3 & 4 & 2.4 & 0 & 0.00 & 1.59 \\
\hline & Total & 354 & 56.2 & 146 & 23.2 & 118 & 18.7 & 9 & 1.4 & 3 & 0.5 & 1.67 \\
\hline \multirow[t]{5}{*}{ Total } & 6 years old & 97 & 49.7 & 49 & 25.1 & 49 & 25.1 & 0 & 0.00 & 0 & 0.00 & 1.75 \\
\hline & 7 years old & 107 & 54.9 & 47 & 24.1 & 37 & 19.0 & 2 & 1.0 & 2 & 1.0 & 1.69 \\
\hline & 8 years old & 166 & 52.7 & 77 & 24.4 & 57 & 18.1 & 11 & 3.5 & 4 & 1.3 & 1.76 \\
\hline & 9 years old & 126 & 52.5 & 64 & 26.7 & 44 & 18.3 & 6 & 2.5 & 0 & 0.00 & 1.71 \\
\hline & Total & 496 & 52.5 & 237 & 25.1 & 187 & 19.8 & 19 & 2.0 & 6 & 0.6 & 1.73 \\
\hline
\end{tabular}

Table 2. Level of boys dental anxiety on dental treatment based on anxiety source

\begin{tabular}{|c|c|c|c|c|c|c|c|c|c|c|c|}
\hline \multirow{3}{*}{ Dental anxiety source } & \multicolumn{11}{|c|}{ Boys dental anxiety level based on anxiety source } \\
\hline & \multicolumn{2}{|c|}{ Not anxious } & \multicolumn{2}{|c|}{ Slightly anxious } & \multicolumn{2}{|c|}{ Anxious } & \multicolumn{2}{|c|}{ Very anxious } & \multicolumn{2}{|c|}{ Extremely anxious } & \multirow{2}{*}{ Average } \\
\hline & $f$ & $\%$ & $f$ & $\%$ & $f$ & $\%$ & $f$ & $\%$ & $f$ & $\%$ & \\
\hline Dentist & 14 & 66.7 & 6 & 28.6 & 1 & 4.8 & 0 & 0.00 & 0 & 0.00 & 1.38 \\
\hline Doctor & 13 & 61.9 & 6 & 28.6 & 2 & 9.5 & 0 & 0.00 & 0 & 0.00 & 1.48 \\
\hline Syringe & 5 & 23.8 & 3 & 14.3 & 11 & 52.4 & 1 & 4.8 & 1 & 4.8 & 2.52 \\
\hline Mouth being examined & 12 & 57.1 & 6 & 28.6 & 3 & 14.3 & 0 & 0.00 & 0 & 0.00 & 1.57 \\
\hline Told to open mouth & 16 & 76.2 & 3 & 14.3 & 2 & 9.5 & 0 & 0.00 & 0 & 0.00 & 1.33 \\
\hline Touched by stranger & 2 & 9.5 & 11 & 52.4 & 7 & 33.3 & 1 & 4.8 & 0 & 0.00 & 2.33 \\
\hline Seen by others & 5 & 23.8 & 11 & 52.4 & 3 & 14.3 & 1 & 4.8 & 1 & 4.8 & 2.14 \\
\hline Burred by dentist & 7 & 33.3 & 4 & 19.0 & 8 & 38.1 & 2 & 9.5 & 0 & 0.00 & 2.24 \\
\hline $\begin{array}{l}\text { See the dentist } \\
\text { burring }\end{array}$ & 11 & 52.4 & 5 & 23.8 & 4 & 19.0 & 1 & 4.8 & 0 & 0.00 & 1.76 \\
\hline Sound of burr & 11 & 52.4 & 6 & 28.6 & 4 & 19.0 & 0 & 0.00 & 0 & 0.00 & 1.67 \\
\hline $\begin{array}{l}\begin{array}{l}\text { Inserted tools into the } \\
\text { mouth }\end{array} \\
\end{array}$ & 12 & 57.1 & 3 & 14.3 & 5 & 23.8 & 0 & 0.00 & 1 & 4.8 & 1.81 \\
\hline Choked & 1 & 4.8 & 5 & 23.8 & 12 & 57.1 & 3 & 14.3 & 0 & 0.00 & 2.81 \\
\hline Go to clinic/hospital & 14 & 66.7 & 5 & 23.8 & 2 & 9.5 & 0 & 0.00 & 0 & 0.00 & 1.43 \\
\hline $\begin{array}{l}\text { People with white } \\
\text { uniform }\end{array}$ & 14 & 66.7 & 6 & 28.6 & 0 & 0.00 & 1 & 4.8 & 0 & 0.00 & 1.43 \\
\hline Nurse cleaning teeth & 5 & 23.8 & 11 & 52.4 & 5 & 23.8 & 0 & 0.00 & 0 & 0.00 & 2.00 \\
\hline
\end{tabular}


Dental anxiety level of children patient using CFSS-DS questionnaire (Mutiara Yuwannisa et al.)

Table 3. Level of girls dental anxiety on dental treatment based on anxiety source

\begin{tabular}{|c|c|c|c|c|c|c|c|c|c|c|c|}
\hline \multirow{3}{*}{ Dental anxiety source } & \multicolumn{11}{|c|}{ Girls dental anxiety level based on anxiety source } \\
\hline & \multicolumn{2}{|c|}{ Not anxious } & \multicolumn{2}{|c|}{ Slightly anxious } & \multicolumn{2}{|c|}{ Anxious } & \multicolumn{2}{|c|}{ Very anxious } & \multicolumn{2}{|c|}{ Extremely anxious } & \multirow{2}{*}{ Average } \\
\hline & f & $\%$ & f & $\%$ & $f$ & $\%$ & $f$ & $\%$ & $f$ & $\%$ & \\
\hline Dentist & 32 & 76.2 & 7 & 16.7 & 2 & 4.8 & 0 & 0.00 & 1 & 2.4 & 1.36 \\
\hline Doctor & 29 & 69.0 & 8 & 19.0 & 4 & 9.5 & 0 & 0.00 & 1 & 2.4 & 1.48 \\
\hline Syringe & 10 & 23.8 & 11 & 26.2 & 19 & 45.2 & 2 & 4.8 & 0 & 0.00 & 2.31 \\
\hline Mouth being examined & 29 & 69.0 & 10 & 23.8 & 3 & 7.1 & 0 & 0.00 & 0 & 0.00 & 1.38 \\
\hline Told to open mouth & 34 & 81.0 & 7 & 16.7 & 1 & 2.4 & 0 & 0.00 & 0 & 0.00 & 1.21 \\
\hline Touched by stranger & 13 & 31.0 & 15 & 35.7 & 12 & 28.6 & 2 & 4.8 & 0 & 0.00 & 2.07 \\
\hline Seen by others & 16 & 38.1 & 14 & 33.3 & 10 & 23.8 & 1 & 2.4 & 1 & 2.4 & 1.98 \\
\hline Burred by dentist & 19 & 45.2 & 11 & 26.2 & 12 & 28.6 & 0 & 0.00 & 0 & 0.00 & 1.83 \\
\hline $\begin{array}{l}\text { See the dentist } \\
\text { burring }\end{array}$ & 27 & 64.3 & 8 & 19.0 & 7 & 16.7 & 0 & 0.00 & 0 & 0.00 & 1.52 \\
\hline Sound of burr & 26 & 61.9 & 10 & 23.8 & 5 & 11.9 & 1 & 2.4 & 0 & 0.00 & 1.55 \\
\hline $\begin{array}{l}\text { Inserted tools into the } \\
\text { mouth }\end{array}$ & 31 & 73.8 & 7 & 16.7 & 4 & 9.5 & 0 & 0.00 & 0 & 0.00 & 1.36 \\
\hline Choked & 6 & 14.3 & 12 & 28.6 & 22 & 52.4 & 2 & 4.8 & 0 & 0.00 & 2.48 \\
\hline Go to clinic/hospital & 32 & 76.2 & 7 & 16.7 & 3 & 7.1 & 0 & 0.00 & 0 & 0.00 & 1.31 \\
\hline $\begin{array}{l}\text { People with white } \\
\text { uniform }\end{array}$ & 37 & 88.1 & 2 & 4.8 & 3 & 7.1 & 0 & 0.00 & 0 & 0.00 & 1.19 \\
\hline Nurse cleaning teeth & 13 & 31.0 & 17 & 40.5 & 11 & 26.2 & 1 & 2.4 & 0 & 0.00 & 2.00 \\
\hline
\end{tabular}

Table 4. Level of 6-years-old children dental anxiety on dental treatment based on anxiety source

\begin{tabular}{|c|c|c|c|c|c|c|c|c|c|c|c|}
\hline \multirow{3}{*}{ Dental anxiety source } & \multicolumn{11}{|c|}{ 6-years-old children dental anxiety level based on anxiety source } \\
\hline & \multicolumn{2}{|c|}{ Not anxious } & \multicolumn{2}{|c|}{ Slightly anxious } & \multicolumn{2}{|c|}{ Anxious } & \multicolumn{2}{|c|}{ Very anxious } & \multicolumn{2}{|c|}{ Extremely anxious } & \multirow{2}{*}{ Average } \\
\hline & $f$ & $\%$ & $\bar{f}$ & $\%$ & $f$ & $\%$ & $f$ & $\%$ & $f$ & $\%$ & \\
\hline Dentist & 8 & 61.5 & 3 & 23.1 & 2 & 15.4 & 0 & 0.00 & 0 & 0.00 & 1.54 \\
\hline Doctor & 8 & 61.5 & 3 & 23.1 & 2 & 15.4 & 0 & 0.00 & 0 & 0.00 & 1.54 \\
\hline Syringe & 4 & 30.8 & 1 & 7.7 & 8 & 61.5 & 0 & 0.00 & 0 & 0.00 & 2.31 \\
\hline Mouth being examined & 11 & 84.6 & 1 & 7.7 & 1 & 7.7 & 0 & 0.00 & 0 & 0.00 & 1.23 \\
\hline Told to open mouth & 10 & 76.9 & 2 & 15.4 & 1 & 7.7 & 0 & 0.00 & 0 & 0.00 & 1.31 \\
\hline Touched by stranger & 4 & 30.8 & 6 & 46.2 & 3 & 23.1 & 0 & 0.00 & 0 & 0.00 & 1.92 \\
\hline Seen by others & 6 & 46.2 & 4 & 30.8 & 3 & 23.1 & 0 & 0.00 & 0 & 0.00 & 1.77 \\
\hline Burred by dentist & 2 & 15.4 & 4 & 30.8 & 7 & 53.8 & 0 & 0.00 & 0 & 0.00 & 2.38 \\
\hline $\begin{array}{l}\text { See the dentist } \\
\text { burring }\end{array}$ & 6 & 46.2 & 4 & 30.8 & 3 & 23.1 & 0 & 0.00 & 0 & 0.00 & 1.77 \\
\hline Sound of burr & 7 & 53.8 & 3 & 23.1 & 3 & 23.1 & 0 & 0.00 & 0 & 0.00 & 1.69 \\
\hline
\end{tabular}




\begin{tabular}{|l|c|c|c|c|c|c|c|c|c|c|c|}
\hline $\begin{array}{l}\text { Inserted tools into the } \\
\text { mouth }\end{array}$ & 9 & 69.2 & 4 & 30.8 & 0 & 0.00 & 0 & 0.00 & 0 & 0.00 & 1.31 \\
\hline Choked & 0 & 0.00 & 5 & 38.5 & 8 & 61.5 & 0 & 0.00 & 0 & 0.00 & 2.62 \\
\hline Go to clinic/hospital & 10 & 76.9 & 2 & 15.4 & 1 & 7.7 & 0 & 0.00 & 0 & 0.00 & 1.31 \\
\hline $\begin{array}{l}\text { People with white } \\
\text { uniform }\end{array}$ & 10 & 76.9 & 1 & 7.7 & 2 & 15.4 & 0 & 0.00 & 0 & 0.00 & 1.38 \\
\hline Nurse cleaning teeth & 2 & 15.4 & 6 & 46.2 & 5 & 38.5 & 0 & 0.00 & 0 & 0.00 & 2.23 \\
\hline
\end{tabular}

Table 5. Level of 7-years-old children dental anxiety on dental treatment based on anxiety source

\begin{tabular}{|c|c|c|c|c|c|c|c|c|c|c|c|}
\hline \multirow{3}{*}{ Dental anxiety source } & \multicolumn{11}{|c|}{ 7-years-old children dental anxiety level based on anxiety source } \\
\hline & \multicolumn{2}{|c|}{ Not anxious } & \multicolumn{2}{|c|}{ Slightly anxious } & \multicolumn{2}{|c|}{ Anxious } & \multicolumn{2}{|c|}{ Very anxious } & \multicolumn{2}{|c|}{ Extremely anxious } & \multirow{2}{*}{ Average } \\
\hline & $f$ & $\%$ & $f$ & $\%$ & $f$ & $\%$ & f & $\%$ & $f$ & $\%$ & \\
\hline Dentist & 8 & 61.5 & 4 & 30.8 & 1 & 7.7 & 0 & 0.00 & 0 & 0.00 & 1.46 \\
\hline Doctor & 6 & 46.2 & 4 & 30.8 & 3 & 23.1 & 0 & 0.00 & 0 & 0.00 & 1.77 \\
\hline Syringe & 3 & 23.1 & 1 & 7.7 & 8 & 61.5 & 0 & 0.00 & 1 & 7.7 & 2.62 \\
\hline Mouth being examined & 10 & 76.9 & 2 & 15.4 & 1 & 7.7 & 0 & 0.00 & 0 & 0.00 & 1.31 \\
\hline Told to open mouth & 12 & 92.3 & 1 & 7.7 & 0 & 0.00 & 0 & 0.00 & 0 & 0.00 & 1.08 \\
\hline Touched by stranger & 4 & 30.8 & 7 & 53.8 & 2 & 15.4 & 0 & 0.00 & 0 & 0.00 & 1.85 \\
\hline Seen by others & 5 & 38.5 & 4 & 30.8 & 4 & 30.8 & 0 & 0.00 & 0 & 0.00 & 1.92 \\
\hline Burred by dentist & 7 & 53.8 & 2 & 15.4 & 3 & 23.1 & 1 & 7.7 & 0 & 0.00 & 1.85 \\
\hline $\begin{array}{l}\text { See the dentist } \\
\text { burring }\end{array}$ & 8 & 61.5 & 4 & 30.8 & 1 & 7.7 & 0 & 0.00 & 0 & 0.00 & 1.46 \\
\hline Sound of burr & 8 & 61.5 & 3 & 23.1 & 2 & 15.4 & 0 & 0.00 & 0 & 0.00 & 1.54 \\
\hline $\begin{array}{l}\text { Inserted tools into the } \\
\text { mouth }\end{array}$ & 8 & 61.5 & 1 & 7.7 & 3 & 23.1 & 0 & 0.00 & 1 & 7.7 & 1.85 \\
\hline Choked & 2 & 15.4 & 5 & 38.5 & 5 & 38.5 & 1 & 7.7 & 0 & 0.00 & 2.38 \\
\hline Go to clinic/hospital & 10 & 76.9 & 1 & 7.7 & 2 & 15.4 & 0 & 0.00 & 0 & 0.00 & 1.38 \\
\hline $\begin{array}{l}\text { People with white } \\
\text { uniform }\end{array}$ & 9 & 69.2 & 4 & 30.8 & 0 & 0.00 & 0 & 0.00 & 0 & 0.00 & 1.31 \\
\hline Nurse cleaning teeth & 7 & 53.8 & 4 & 30.8 & 2 & 15.4 & 0 & 0.00 & 0 & 0.00 & 1.62 \\
\hline
\end{tabular}

Table 6. Level of 8-years-old children dental anxiety on dental treatment based on anxiety source

\begin{tabular}{|c|c|c|c|c|c|c|c|c|c|c|c|}
\hline \multirow{3}{*}{ Dental anxiety source } & \multicolumn{11}{|c|}{ 8-years-old dental anxiety level based on anxiety source } \\
\hline & \multicolumn{2}{|c|}{ Not anxious } & \multicolumn{2}{|c|}{ Slightly anxious } & \multicolumn{2}{|c|}{ Anxious } & \multicolumn{2}{|c|}{ Very anxious } & \multicolumn{2}{|c|}{ Extremely anxious } & \multirow{2}{*}{ Average } \\
\hline & $f$ & $\%$ & $f$ & $\%$ & $f$ & $\%$ & $f$ & $\%$ & $f$ & $\%$ & \\
\hline Dentist & 17 & 81.0 & 3 & 14.3 & 0 & 0.00 & 0 & 0.00 & 1 & 4.8 & 1.33 \\
\hline Doctor & 15 & 71.4 & 4 & 19.0 & 1 & 4.8 & 0 & 0.00 & 1 & 4.8 & 1.48 \\
\hline Syringe & 4 & 19.0 & 6 & 28.6 & 10 & 47.6 & 1 & 4.8 & 0 & 0.00 & 2.38 \\
\hline Mouth being examined & 12 & 57.1 & 8 & 38.1 & 1 & 4.8 & 0 & 0.00 & 0 & 0.00 & 1.48 \\
\hline
\end{tabular}


Dental anxiety level of children patient using CFSS-DS questionnaire (Mutiara Yuwannisa et al.)

\begin{tabular}{|l|c|c|c|c|c|c|c|c|c|c|c|}
\hline Told to open mouth & 17 & 81.0 & 3 & 14.3 & 1 & 4.8 & 0 & 0.00 & 0 & 0.00 & 1.24 \\
\hline Touched by stranger & 2 & 9.5 & 8 & 38.1 & 9 & 42.9 & 2 & 9.5 & 0 & 0.00 & 2.52 \\
\hline Seen by others & 6 & 28.6 & 9 & 42.9 & 4 & 19.0 & 1 & 4.8 & 0 & 0.00 & 1.86 \\
\hline Burred by dentist & 9 & 42.9 & 7 & 33.3 & 4 & 19.0 & 1 & 4.8 & 0 & 0.00 & 1.86 \\
\hline $\begin{array}{l}\text { See the dentist } \\
\text { burring }\end{array}$ & 8 & 61.5 & 4 & 30.8 & 1 & 7.7 & 0 & 0.00 & 0 & 0.00 & 1.46 \\
\hline Sound of burr & 8 & 61.5 & 3 & 23.1 & 2 & 15.4 & 0 & 0.00 & 0 & 0.00 & 1.54 \\
\hline $\begin{array}{l}\text { Inserted tools into the } \\
\text { mouth }\end{array}$ & 8 & 61.5 & 1 & 7.7 & 3 & 23.1 & 0 & 0.00 & 1 & 7.7 & 1.85 \\
\hline Choked & 2 & 15.4 & 5 & 38.5 & 5 & 38.5 & 1 & 7.7 & 0 & 0.00 & 2.38 \\
\hline Go to clinic/hospital & 10 & 76.9 & 1 & 7.7 & 2 & 15.4 & 0 & 0.00 & 0 & 0.00 & 1.38 \\
\hline $\begin{array}{l}\text { People with white } \\
\text { uniform }\end{array}$ & 9 & 69.2 & 4 & 30.8 & 0 & 0.00 & 0 & 0.00 & 0 & 0.00 & 1.31 \\
\hline Nurse cleaning teeth & 7 & 53.8 & 4 & 30.8 & 2 & 15.4 & 0 & 0.00 & 0 & 0.00 & 1.62 \\
\hline
\end{tabular}

Based on Figure 3, when viewed based on the source of anxiety, most girls felt anxious about choking $(52,4 \%)$, and anxiety about the syringe $(45.2 \%)$. These data suggested that boys were generally anxious to be choked and syringes during dental treatment (Table 3).

According to Table 3, when viewed on the basis of anxiety sources, most 6-year-olds were anxious about syringes $(61.5 \%)$, then anxiety of choking there were $61.5 \%$. These data suggested that 6-year-olds were generally anxious about syringes and choking during dental treatment (Table 4).

From Table 4, when viewed based on the source of anxiety, most 7-year-olds were anxious to syringes $(61.5 \%)$, then anxiety of choking were $38.5 \%$. These data suggested that 6-year-olds are generally anxious about syringes and choking during dental treatment.

In children aged 8 years, highest number causes of anxiety were syringe $(47.6 \%)$, and touched by strangers (42.9\%) (Table 5 ). These data suggested that 8-year-olds were generally anxious to choking and syringes as well as being touched by foreigners during dental treatment.

From Table 6, children aged 9 years have the highest number of choking $(81.3 \%)$ as source of anxiety, and dentist's burr (37.5\%). These data suggested that 9-year-olds were generally anxious to choking and to dentist's burr during dental treatment.

\section{DISCUSSION}

The results showed that there was difference in the percentage of anxiety based on age and sex by using CFSS-DS questionnaire descriptively. This explained that the situation of dental treatment influenced the emergence of anxiety. ${ }^{12}$

Based on the age of sample that can be seen in Table 1, it could be concluded that 6-yearolds were anxious about dental treatment (25.1\%) from 63 samples. While 7-year-old children felt not anxious about dental treatment (54.9\%). Children aged 8 years old were very anxious about dental treatment (3.5\%), and children aged 9 years felt a slightly anxious about dental treatment (26.7\%). The results were mimicking the opinion of Winner (1982). Winner concluded that there was an indication of increasing anxiety in dental treatment in children as age increases, especially after the age of 7-8 years. Then, it rose significantly at the age of 9-12 years. This was because older children were better at understanding than younger children.13 In addition, older children certainly had a greater risk of receiving dental treatment than young children. ${ }^{14}$

Based on the gender that could be seen in Table 1, from samples of 21 boys and 42 girls, it concluded that boys generally felt more anxious than girls. The results of this study were parallel with research conducted by Liddell and Murray, who said that the level of anxiety in dental treatment of girls were greater than boys. Liddell 
and Locker (1991) also stated that this difference was due to the perception that women had weaker controls in dental procedures and more open in expressing their anxieties. In contrast to men which had better ability to cover up feelings of anxiety by turning anxiety or fear into an anger. ${ }^{15}$

Other studies had suggested that women had a lower pain threshold than men, so women' tolerance for pain were low. In this study, it was found that children of male gender had anxiety level higher than the female child. This could be influenced by several factors, such as the influence of families who always considered boys were strong - not weak, socioeconomic factors of children (low socioeconomic groups had a higher anxiety than children from middle and high socioeconomic groups), as well as environmental factors or foreign situations that may cause anxiety in children, because the child was not yet ready for a new environment and required adjustment to the new environment.

The arising of anxiety was generally a personal assumption due to the patient's ignorance of the treatment that is performed by the dentist. ${ }^{17}$

Table 2 showed the level of anxiety of boys during dental treatment. These data suggest that boys in general were anxious of choking and syringes. The results of this study were in accordance with the literature, which stated that injection was a painful procedure whereas pain was the originator of anxiety and fear in dental care. 18

Anxiety was an unpleasant situation associated with threatening or imagined pain. ${ }^{19}$ Table 3 showed girls' anxiety levels in dental care. Based on the research, source of anxiety results similar between boy and girl during dental treatment. These data indicated that girls are generally anxiously choking and syringes during dental treatment. It was related to the child's imaginative anxiety that develops during this age so that the child was able to think abstractly and could imagine something unpleasant, creepy, or scary that injection or choking would cause pain.

In Table 4, which showed anxiety levels of 6-year-olds during dental treatment, it was found that the highest-level source of anxiety was syringe whereas the lowest-level source of anxiety was someone checking your mouth. Table 4 and
5 showed the highest level source of anxiety in 7-year-olds during dental treatment was syringe and the lowest was opening the mouth. The results of this study related to an unpleasant child's experience of syringes during dental treatment. Such unpleasant treatment can cause anxiety in children. It caused children to experience feeling of fear and anxiety when treated by a dentist. ${ }^{17}$

In Table 6 showed the source of anxiety in an 8-year-old's anxiety during dental treatment. It was found that the highest-level source of anxiety was the syringe whereas the lowest was dentists, doctors, and white-uniformed people. Table 7 showed the anxiety level of 9-year-olds, it was found that the highest-level source of anxiety was choking and the lowest was found in dentists, doctors, and white-uniformed people. These results indicated that the more mature the child got, the more different source of anxiety was from children at their younger age. According to Piaget's analysis, as the age increases, the child's view of rules began to change from rigid rules to more flexible rules. Children began to understand and associate to every form of behavior due to the concept of right-wrong or good-bad. ${ }^{21}$

Based on the data, it could be concluded that the highest level of child's anxiety at the age of 6-9 years was found in syringe. This was because the patient facing a possible shadow, and often worse than the event itself, or the patient had a previous traumatic experience with the syringe. 12 Anxiety and fear of syringes in accordance with Kleinknecht's (1973) study suggested that an injection procedure was considered the most frightening procedure to the patient. ${ }^{22}$

Liddell and Locker (1991) also stated that there was a relationship between anxiety status with unpleasant experiences in dental treatment, one of which was the pain that could be found in invasive treatments. Based on the results of research conducted on children aged 6-9 years in Pedodontic Installation RSGM University Padjadjaran, invasive measures such as syringe in injection procedure and choking on dental treatment were the most prevalent source of anxiety of children. ${ }^{15}$

\section{CONCLUSION}

The anxiety level of children patients during 
dental treatment were different based on their age and gender.

\section{REFERENCES}

1. Alwisol. Psikologi Kepribadian. Malang: UMM Press; 2005.

2. Psikologi [homepage on internet]. Pratiwi RP. 2010. Pengertian Kecemasan. [cited 2011 May]; [about 6 screens]. Available from: http://psikologi.or.id/mycontents/ uploads/2010/05/pengertian-kecemasananxiety.pdf

3. Taylor S. Nature and measurement of anxiety sensitivity. J Anx Disorder. Sep-Oct 1996;10(5):p. 425-51.

4. Inspired Kids Magazine [homepage on internet]. Zoelandri M. 2009. Mengelola rasa takut anak. [cited 2011 Feb]; [about 4 screens]. Available from: http://www.inspiredkidsmagazine. com/ArtikelPsychology.php?artikelID=20.8.

5. Joelimar FA. Dental Anxiety : Salah satu faktor penghambat dalam pemanfaatan jasa kedokteran gigi. 7th Scientific Meeting and Refresher Course in Dentistry (KPPIKG VII); 1986; Jakarta, Indonesia. p. 424-28.

6. Corah NL, Gale EN, Illig SJ. Assesment of dental anxiety scale. J Am Dent Assoc. 1978 Nov;97(5):816-9.

7. Dention [homepage on internet]. Maulani C. 2006. Hii takut. [cited 2011 Feb]; [about 2 screens]. Available from: http:// dention.bravehost.com/hii_takut.html

8. Folayan MO, Kolawole KA. A critical appraisal of the use of tools for assessing dental fear in children. Afr J Oral Health. 2004;1(1):54-63.

9. Notoatmodjo S. Metodologi penelitian kesehatan. Jakarta: Rineka Cipta; 2005. p. 141.

10. Sugiyono. Statistika Untuk Penelitian.
Bandung: Alfabeta; 2011. p. 67.

11. Sudjana A. Metode Statistika. Bandung: Tarsito; 2005. p. 168.

12. Sutadi H, Heriandi Y. Rasa Takut atau Cemas Terhadap Perawatan Gigi. Kumpulan Makalah Ilmiah Kongres PDGI; 1994; Jakarta, Indonesia. p. $135-40$.

13. Winer GA. A Review and Analysis of Children's Fearful Behavior in Dental Setting. Child Dev. 1982 Oct;53(5):1111-33.

14. Liddell A, Murray P. Age and sex differences in children's reports of dental anxiety and self-efficacy relating to dental visits. Canad J Behav Sci. 1989;21(3):270.

15. Locker D, Liddell AM. Correlates of dental anxiety among older adults. J Dent Res. 1991 Mar;70(3):198-203.

16. Finn SB. Clinical Pedodontics. 4th ed. Philadelphia: Saunders-Elsevier; 2003. p. 1-17, 43.

17. Sumawinata N. Rasa takut atau cemas terhadap perawatan gigi. 10th Scientific Meeting and Refresher Course in Dentistry (KMIKPPIKG X); 2004; Jakarta, Indonesia. p. 75-86.

18. Marks HS, The genesis of fear and anxiety in young dental patient. ASDC J Dent Child. 1978 Jul-Aug;45(4):306-9.

19. Hurlock EB, Development Psychology. 6th ed. New York: McGraw-Hill, Inc.; 1978.

20. Gunarsa SD. Pendekatan dan penanganan psikologik terhadap anak dalam menghadapi perawatan giginya. Forum Ilmiah Fakultas Kedokteran Gigi Universitas Trisakti; 1984; Jakarta, Indonesia. p. 261-5.

21. Yusuf SH. Psikologi Perkembangan Anak dan Remaja. Bandung: PT Remaja Rosdakarya; 2011.

22. Kleinknecht RA, Klepac RK, Alexander LD. Origins and Characteristics of fear of dentistry. J Am Dent Assoc. 1973 Apr;86(4):842-8. 